\title{
GYRFALCONS IN RUSSIA: CURRENT STATUS AND CONSERVATION PROBLEMS
}

\author{
Eugene Potapov \\ Bryn Athyn College, Bryn Athyn, PA 19009, USA. \\ E-mail: eugenepotapov@gmail.com
}

\begin{abstract}
The range of the Gyrfalcon (Falco rusticolus) in Russia covers c. 2,685,000 km² which constitutes $37 \%$ of its total range. Some recent findings suggest an even larger range once extended further south. So far, studies of the species within Russia have been limited, and longterm monitoring has occurred in only a few locations, such as southern Yamal and northern Kamchatka Peninsula. I monitored the Gyrfalcon population in North East Sakha (Yakutia), Russia, in 1985-1995 and used published and unpublished information on the species obtained through personal contacts in the Arctic. The majority of the studies demonstrated a close association of the Gyrfalcon with Willow Ptarmigan (Lagopus lagopus). In some regions, the nest sites were disturbed by oil pipeline installations; however, in other places, abandoned oil extraction rigs provided new nest substrates for the Gyrfalcons and thus benefitted the species. None of the monitoring efforts were detailed enough to demonstrate the cyclic abundance of ptarmigan populations and its effect on the Gyrfalcon. In addition, some researchers chose not to publish the results of their findings on the species for fear that the nests in the described study areas would be robbed by falcon traders. Every year the authorities confiscate many Gyrfalcons bound for export. The official numbers of total Gyrfalcon exports from Russia are relatively small compared to other countries, but the numbers of Gyrfalcons confiscated annually by authorities often exceed the official export numbers. In general, the Gyrfalcon in Russia lacks attention by scientists; topics of particular conservation interest include the possible impact of oil and gas field development in some regions, and the implications of current alarming rates of illegal harvest. Received 13 June 2011, accepted 16 June 2011.
\end{abstract}

Potapov, E. 2011. Gyrfalcons in Russia: Current status and conservation problems. Pages 191-196 in R. T. Watson, T. J. Cade, M. Fuller, G. Hunt, and E. Potapov (Eds.). Gyrfalcons and Ptarmigan in a Changing World, Volume II. The Peregrine Fund, Boise, Idaho, USA. http://dx.doi.org/10.4080/gpcw.2011.0218

Key words: Conservation, Gyrfalcon, illegal, Russia, status, trapping, legislation.

THE GyRFALCON (Falco rusticolus), the largest falcon in the world, lives in the Arctic and subArctic, and relies heavily on ptarmigan as its major food source, and a few other species, such as Ravens (Corvus corax), Rough-legged Hawks (Buteo lagopus), and some eagles, to build nests which it uses for breeding. Despite its dependence on prey species that exhibit cycles of abundance, the Gyrfalcon has enjoyed relative population stability, as its breeding range was too remote from potential human-caused threats. Within the Russian Federation, the Gyrfalcon's range covers c. $2,685,000 \mathrm{~km}^{2}$ of tundra and forest-tundra, 
which constitutes about $37 \%$ of the species' total range. The tundra within its range was relatively undeveloped, with few cities, and only a few regions with a somewhat detectable network of roads. However the economic development of the past two decades has changed this situation, and the change of political system has shattered the previously existing network of legislation and law enforcement.

\section{Legal Status}

In the time of the Union of Soviet Socialist Republics (USSR), the Gyrfalcon was persecuted together with other 'harmful' birds of prey, and a bounty was paid by the state until 1964, when the Glavokhota (USSR analogue of US Fish and Wildlife Service) protected the Gyrfalcon under order \#173 from 1 July 1964. Under this legislation the species enjoyed full protection. It was prohibited to shoot, capture, or to disturb the nest of Gyrfalcons. This legislation was reinforced by a special resolution entitled "Penalties for the illegal extermination of the Red Data Book Species" of 25 October 1985, passed by the Ministry of Agriculture of the USSR. Under this legislation, the penalty for shooting a Gyrfalcon was the maximum possible and set at 500 Roubles (at the time, this was the cost of four round trips from Kamchatka to Moscow by air). It is difficult to provide a US dollar equivalent for this time period, since free currency exchange was not permitted by the Communist Party and Soviet government.

Currently, the Gyrfalcon is protected by Federal Law \#7 FZ "On the Protection of the Environment" of 10 January 2002 and the Federal Law on the Animal Kingdom, initially adopted on 22 March 1995, and amended on 2 November 2004 (\#127FZ), 29 December 2004 (\#199 FZ), 31 December 2005 (\#199 FZ), 18 December 2006 (\#232 FZ), 29 December 2006 (\#258 FZ), 20 April 2007 (\#57 FZ), and 3 December 2008 (\#250 FZ).
Under this legislation it is strictly prohibited to remove, shoot, utilize, disturb, possess or sell animals listed in the Red Data Book of Russia. Amendment was made for scientific and conservation projects involving these species, the Gyrfalcon included. Permission for implementation of such projects is given by the organization called Rosprirodnadzor, after consultation with a board of experts. The Rosprirodnadzor is a federal service run by the Ministry of Natural Resources, which executes and enforces the law on the utilization of natural resources and their conservation. The board of experts is appointed by the Rosprirodnadzor from major conservation bodies in Russia and also includes scientists working with the species of concern.

After the USSR joined the Convention on International Trade of Endangered Species (CITES) on 8 December 1976, it adopted new legislation from 4 August 1976 called Special Decree \#612 of the Council of Ministers of the USSR. Once again, the Decree specifically prohibited shooting (or removal from the wild) raptors, the Gyrfalcon included, without prior permission by the Ministry of Agriculture. The Russian Federation officially acknowledged its successor responsibilities under the CITES agreement immediately after the USSR dissolved itself on 13 January 1992. Internationally, the Gyrfalcon has enjoyed the legal protection of CITES since 1979 as an Appendix I species (i.e., no commercial trade). Currently, therefore, Gyrfalcons have the maximum protection international law can provide.

In general, keeping the Gyrfalcon in CITES Appendix I serves the species well, especially if legislation in range countries is effective and management practices are transparent. Let us hope that the remote breeding grounds of the species will be as productive as ever, and that although the numbers of Gyrfalcons within its present range will fluctuate naturally, as they always have, the population of this most majestic falcon will remain stable. 


\section{Threats and Conservation Problems}

In Russia, the threats to Gyrfalcons come from the oil industry and development of road infrastructure, Arctic Fox (Vulpes lagopus) trapping, and illegal and ignorant removal of falcons, their eggs and chicks from the wild. Threats like direct hunting and persecution are already in the past. So far there is no evidence of dramatic decline in the principal prey of the Gyrfalcon, the ptarmigan (Lagopus sp).

The oil industry is currently expanding in Nenets National District of the European part of Russia, in Western Siberia, and in particular in Yamal Peninsula. These regions are known to accommodate healthy populations of Gyrfalcons. The oil industry does not affect the Gyrfalcons directly, but facilitates development of roads, which are used by illegal bird trappers. An oil development proposed for the Anadyr district caused fear that the Gyrfalcon breeding grounds would be affected in one way or another. Other regions in the Arctic, apart of the Norilsk environs, are not affected by the development, and do not have a developed network of roads and railways.

Arctic Fox trapping was perhaps the main threat to Gyrfalcons in the 1980s; however, the demise of the international fur trade in early 1990 has dramatically decreased trapping in the Russian Arctic (Potapov and Sale 2005, Sale and Potapov 2010), and by now the trapping effort has declined c. 100 times. Gyrfalcons were caught in leg traps in winter, and their meat was utilized as bait in the traps. Chuvashov (1989) reported that the meat of Rough-legged Buzzards (Buteo lagopus), Snowy Owls (Bubo scandiaca) and falcons (Peregrines Falco peregrinus and Gyrfalcons) is considered to be a delicacy among nomadic peoples, particularly the Nenets of Russia's Gydan Peninsula, who shoot the birds during spring as they return to the area to breed.

\section{Disturbance AND Illegal Shooting}

Kalyakin (1989) suspected Reindeer (Rangifer tarandus) herders of destroying three or four Gyrfalcon nests during his study in Russia's Yamal, and illegal shooting by Reindeer herders was also noted by Morozov (1991) as a probable cause of a Gyrfalcon death in the Arctic Urals. Human disturbance is almost certainly the reason for the low breeding density of Gyrfalcons around the Vorkuta industrial zone (Morozov 1991). Kalyakin and Vinogradov (1981) also reported direct persecution of a nest of Gyrfalcons in southern Yamal in 1979 and 1980. Shooting of Gyrfalcons by trackers on the winter road from Cherskiy (Yakutia) to Bilibino (Chukotka) was reported to me in the late 1980s in the Lower Kolyma.

\section{ILLEGAL AND IGNORANT REMOVAL OF GYRFALCONS FROM THE WILD}

In Russia, from the $13^{\text {th }}$ to $18^{\text {th }}$ Centuries, Gyrfalcon trapping was a monopoly of the Tsar (Shergalin 2011). In medieval times, the Novgorod Principality dominated the trade, as it controlled most of the trade routes to the Urals and the White Sea. Later, when the Principality lost its independence, falcon trapping became one of the duties of sovereign subjects (Dementiev 1951, 1960). Teams of falcon trappers (promyshlenniky)_-sometimes working as fur trappers as well-went to remote areas of Russia's North. The trappers were prohibited from selling Gyrfalcons - the Tsar had a monopoly on Gyrfalcon ownership-their entire catch having to be taken to Moscow. The falcons were brought by sleigh, and the trappers were granted a food allowance of two kopeks per day for each bird (Dementiev 1951). The trappers themselves were entitled to receive food and accommodation free from the villages through which they traveled, on production of their authority from the Tsar. In the $16^{\text {th }}$ Century, falcon trappers and the fal- 
coners at the Tsar's Court were covered by a special legislation - the Uryadink (Legislation) of the Falconry Path (Uryadnik 1788) - which defined both their duties and their behavior'Falconers (sokolniki) of the Royal Mews found drunken, quarrelsome, intriguing or merely stupid are to be transported in chains to the Lena.'

By the end of the $17^{\text {th }}$ Century, the demand for Gyrfalcons started to decline. A note from the time tells the Governor of the Upper Tura region of Siberia not to supply any more Gyrfalcons to Moscow, although trapping did continue: in the 1730s the Arkhangelsk and Rostov falcon trappers were given permission to catch Gyrfalcons for themselves on condition that they supplied 20 females and 30 males to the Royal Mews (Dementiev 1951). The Rostov falcon trappers ceased to exist in 1787, and other groups stopped their activities in the early 1800 s.

Today, the Russian Ministry of Nature Resources (Ministry of Agriculture in the past) permits removal of wild falcons for selected falcon propagation centers under special license. No commercial trade officially exists, but there are numerous stories of the illegal removal of Gyrfalcons from traditional breeding places. Not all such stories are hearsay. In autumn 1994, the then Prime Minister of the Russia Federation, Viktor Stepanovich Chernomyrdin, decided that during a visit to a Middle East country he would present the ruler a pair of Russian Gyrfalcons. He hired two falconers who went to Magadan (where Alaskan and Chukotkan Gyrfalcons can be found) and, assisted by the Russian secret police, the FSB (formerly the KGB), trapped two Gyrfalcons (P. Dudin, pers. comm.). Each falconer received an SUV as compensation for their services, but the public outcry prevented the export of the birds, which are still kept at a centre in Moscow.

Gorovenko (2002) gives details on the population of Gyrfalcons in Koryakia, Kamchatka.
Out of eight nests that he monitored, at least one nest was robbed by trappers. Lobkov et al. (2011) mentions an on-going problem in Kamchaka with illegal trapping of Gyrfalcons. In fact, Kamchakta turned into a battlefield between the illegal trappers and conservationists in the past decade. The number of falcons taken from Kamchatka was believed to threaten the well-being of the entire Kamchatka population (Lobkov 2000). Cases of illegal trapping are known in Chukotka and in the Magadan area, where numerous attempts were made to transport Gyrfalcons using permits issued for Goshawks.

\section{ROLE OF INFORMATION}

Scientists studying Gyrfalcons in various countries are facing a tremendous challenge. As soon as a study is published, it can be read by thousands of people who may have different intentions. Most potential poachers will specifically look for the location of nests, or at least a region with a proven concentration of the Gyrfalcons. Try to put yourself in a poacher's shoes: you just struck a lucrative deal with a rich enough buyer and have to supply (legally or illegally) chicks, eggs, or adults . Where would you go? To any place where some proven breeding (or migration concentration) of Gyrfalcons is taking place. Unsurveyed (or unpublished) places are not of any interest as they involve too much risk, and therefore might not be economical. However, the places with a proven record of breeding (even passed the peer reviewers eyes or publisher approval) are a sure shot. There is little wonder that the well-published Gyrfalcon locations in an isolated, and hence easy to locate, forest patch surrounded by the tundra at the More- $\mathrm{U}$ and Bolshaya Rogovaya rivers (Voronin 1977, 1983, 1984) no longer exist. A generation of both legal and illegal trappers continuously took chicks from the nest and attempted (sometimes successfully) to trap parents. This happened not only in Russia. Famous and well known breeding places on Ungava were described with pictures in a 
superb well-illustrated book on Gyrfalcons by Emma Ford (1999). One of the pictures covered an area in Quebec, which was very easy to identify. No wonder that on 12 May 2002, UK and South African nationals were caught with seven eggs of Gyrfalcons taken from this location. They posed as wildlife photographers to charter a helicopter for a reconnaissance trip. An alert was raised when they showed a special interest in the nests of Peregrines and Gyrfalcons. The men were arrested and charged with six counts of illegal possession of eggs, hunting without a license, and were fined $\$ 7250$ - the maximum permitted by Quebec's wildlife legislation (Anon 2002).

Such examples of misuse of information impose a severe constraint on the publication of data on Gyrfalcons in Russia. There are currently at least two research projects on Gyrfalcons in Russia which refuse to publish their results in scientific literature. Some researchers tend not to study this species simply because the hand of an illegal trapper or an unjustified permit from Moscow might affect the sample size of their study animal.

\section{Current Developments}

In February 2011, the Governor of Kamchatka, Mr. A. Kuzmitskiy, led an initiative to amend the Criminal Code with the punishments for violation of Nature Conservation Laws. It was a significant change from the current law, which treats such incidents under the Civil Law Code with significantly gentler punishments. Kuzmitskiy said at the Duma meeting that the illegal trapping of Gyrfalcons occurs in all regions of Kamchatka, and will lead to the demise of the entire Kamchatka population. The initiative was adopted by the Kamchatka Duma and there is hope that this local legislative body will submit relevant documents to the State Duma shortly. Sadly, for reasons not explained to the public, $\mathrm{Mr}$. Kuzmitskiy was relieved from his duties by the President D. Medvedev on 25 February 2011.
Just recently, a private zoo in Germany via a private breeder in Moscow District was issued a license to remove 15 eggs from the Anadyr region, Chukotka, Russia. The justification of the license was based on the assumption that the "Gyrfalcons will lay more eggs if the eggs would be removed from the nest." Laying a second clutch is well-documented in captive falcons, but nobody has yet observed such a phenomenon in the wild. However, the assumption was submitted by the licensee, and to the surprise of many, it was adopted by the commission of Rosprirodnadzor, an organization that supervises rare animal species. The Rosprirodnadzor violated their own regulation, which prescribes the use of scientific expertise for evaluation of such projects, and did not demonstrate a conservation value of the project or document any monitoring in the Anadyr region. Only public outcry in the mass media and pending litigation postponed the action (Ganusevich pers. comm., Ganusevich 2011).

\section{Literature Cited}

ANON. 2002. Eggs seized in Quebec. Legal Eagle 34:7.

Chuvashov, G. I. 1989. Deaths of rare species of falcons and other rare birds in Gydan Peninsula. Pages 246-248 in V. A. Kuzyakin (Ed.). Proceedings of the Surveyed Characteristics, Results of Counts and Materials of the Surveys on Non-Commercial Birds, Reptiles, Amphibians, and Fish. Bashkir Books, Ufa, Russia (in Russian).

Dementiev, G. P. 1951. Falcons-Gyrfalcons. Materials on the study of the Fauna of the USSR. Proceedings of the Moscow Society of Naturalists, Department of Zoology, New series N29 (in Russian).

Dementiev, G. P. 1960. Der Gerfalke (Falco gyrfalco L. = Falco rusticolus L.). Die Neue Brehm-Bücherei, no. 264. A. Ziemen Verlag, Wittenberg Lutherstadt, Germany. ForD, E. 1999. Gyrfalcon. John Murray Press, London, UK. 
Ganusevich, S. 2011. [Decision to remove Gyrfalcon eggs spark protests by international science community]. Russian News (in Russian). http://eco.rian.ru/nature/ 20110510/372674285.html

GorovenKo, A. V. 2002. [Distribution and numbers of Gyrfalcon Falco rusticolus grebenitskii in the North of the Kamchatka peninsula]. Pages 42-48 in A. M. Torkanov (Ed.). Proceedings of the $3^{\text {rd }}$ scientific conference: Conservation of Biodiversity of Kamchatka and its Coastal Waters, 26-27 November 2002. KamchatskNIRO, Petropavlovsk-Kamchatskiy, Russia (in Russian).

KaLYAKIN, V. N. 1989. Birds of prey in extreme north ecosystems. Pages 51-112 in Yu. I. Chernov (Ed.). Birds in the Natural Communities of the Tundra Zone. Nauka, Moscow, Russia (in Russian).

KALYAKIN V. N., AND V. G. VinOGRADOV. 1981. [On breeding of Gyrfalcons in the south of the Yamal Peninsula]. Bulletin of the Moscow Society of Naturalists, Department of Zoology, 86(5):42-51.

Lobkov, E., YU. Gerasimov, AND A. Gorovenko. 2011. Status of the Kamchatka Gyrfalcon (Falco rusticolus) population and factors affecting it. In $\mathrm{R}$. $\mathrm{T}$. Watson, T. J. Cade, M. Fuller, G. Hunt, and E. Potapov (Eds.). Gyrfalcons and Ptarmigan in a Changing World. The Peregrine Fund, Boise, Idaho, USA. http://dx. doi.org/10.4080/gpcw.2011.0127

Loвкоv, E. G. 2000. Illegal trapping and export of Gyrfalcons from Kamchatka is a threat to the very exsistence of the Kamchatka population. Pages 115-119 in R. S. Moiseev (Ed.). Proceedings of the $1^{\text {st }} \mathrm{Sci}$ entific Conference: Conservation of Biodiversity of Kamchatka and its Coastal Waters, 11-12 April 2000, KamchatskNIRO, Petropavlovsk-Kamchatskiy, Russia (in Russian).
Morozov, V. V. 1991. Peregrine and Gyrfalcon in the extreme North-East of Europe. Bulletin of the Moscow Society of Naturalists, Biology Series 96(1):57-65 (in Russian).

Potapov, E., ANd R. SAle. 2005. The Gyrfalcon. T. \& A. D. Poyser, London, UK, and Yale University Psress, New Haven, Connecticut, USA.

Sale, R., AND E. Potapov. 2010. Scramble for the Arctic. Frances Lincoln Ltd., London, UK.

SHERGALIN, J. 2011. Gyrfalcon trappers in the Russian Arctic in the $13^{\text {th }}-18^{\text {th }}$ Centuries. In R. T. Watson, T. J. Cade, M. Fuller, G. Hunt, and E. Potapov (Eds.). Gyrfalcons and Ptarmigan in a Changing World. The Peregrine Fund, Boise, Idaho, USA. http://dx.doi.org/10.4080/gpcw.2011.0306

URYADNIK (Legislation). 1788. [Legislation on falconry and trapping] Kniga glagolemaya uryadnik: novoye ulozhenie I china sokolnich'ya puti. In Ancient Russian History, vol. $3,2^{\text {nd }}$ ed. Published by N. Novikov (in Russian).

VORONIN, R. N. 1977. [Materials on the biology of Peregrines and Gyrfalcons in the Bolshezemelskaya Tundra]. Pages 203-204 in M. A. Voinstvenskiy (Ed.). Proceedings of the $7^{\text {th }}$ All-Union Ornithological Conference, vol. 2. Naukova Dumka Press, Kiev, Ukraine (in Russian).

VORONIN, R. N. 1983. [Influence of the Gyrfalcon on the population structure of Willow Grouse in the Bolshezemelskaya tundra]. Structure of the bird population of the European part of NW USSR. Proceedings of the Komi Branch of the Academy of Sciences. Syktyvkar 62:17-20 (in Russian). VORONIN, R. N. 1984. [Daily activity of the Gyrfalcon during the chick rearing period in the Bolshezemelskaya tundra]. Pages 72-75 in M. I. Braude (Ed.). Fauna of the Urals and Adjoining Territories. Ural State University Publishers, Sverdlovsk, Yekaterinburg, Russia. 